\title{
MILITARY SUPPLY NETWORK AT RISK
}

\author{
Andreas ALEXA \\ National Defence Academy, Vienna, Austria \\ andreas.alexa@bmlv.gv.at
}

\begin{abstract}
An efficient supply network is a basic building block of a globalized society and an essential element for maintaining the sustainability of armed forces in an operation. However, the increased optimization of supply chains, the integration of various partners and the resulting complexity increase the vulnerability of supply networks. The protection of internal and external supply chains is therefore important. In order to be better prepared for the future, it is therefore necessary to strengthen the resilience of the military supply network. To this end, risk management must be implemented at the appropriate military command levels in order to be able to take the right measures. Starting with the military strategic level and continuing to the operational and tactical level, a consistent, plausible and functioning instrument dealing with risk management planning, risk identification, risk analysis and evaluation, risk treatment, and risk monitoring must be introduced.
\end{abstract}

\section{Keywords: Military Logistics, supply network, risk management}

\section{Introduction}

An efficient supply network is a basic building block of a globalized society and an essential element for maintaining the sustainability of armed forces in an operation. However, the increased optimization of supply chains and the resulting increasingly complex and time-critical supply networks also increase the vulnerability to risks, which can pose a threat to the existence of companies or jeopardize the fulfilment of orders in military operations. The protection of internal and external supply chains is therefore becoming more and more important. This applies equally to the civilian logistics industry and to military logistics.

Crises, such as the COVID-19 pandemic or the blockade of the Suez Canal at the beginning of April 2021 by one of the biggest container ships, are precisely what contribute to disruptions in the supply network or to its complete collapse. This poses major challenges for civilian companies and armed forces alike when it comes to securing supplies for their customers. Risks can affect the supply network in different ways, and the question is what can be done to create greater supply network resilience.

Therefore, the following article discusses the supply network first in general and second with a focus on the military, and presents then the risk management process in detail.

\section{Supply Network}

In principle, in a network different actors with the same characteristics or interests work together in a coordinated manner to achieve a common goal [1]. Although the elements enter into a form of symbiosis with special relationships, they remain largely autonomous [2]. The purpose of network formation is to promote productivity by exploiting the advantages of cooperative behaviour and a pooling of strengths to increase flexibility and innovation [3].

Modern logistics networks are complex systems consisting of subsystems with 
different functions, based on the concept of cross-company flows. Material, but also people or information flow from sources via nodes to sinks. By this, they overcome spatial and temporal differences as well as company boundaries. This is often accompanied by a transformation in terms of quantities, types, handling properties and associated information.

It is important to design the network relationships, focused on the business, social and information relations. This also includes targeted influencing as well as monitoring of the cooperation partner in order to permanently secure the goals of the cooperation. Another important aspect is leadership. On the one hand, this involves the distribution of leadership competence for the entire network and, on the other hand, it involves the personal leadership of those employees who work precisely at the interfaces between the companies [4]. Here, it is important to establish cross-company problem-solving mechanisms at an early stage. Goal, role, power and communication conflicts must be counteracted on an ongoing basis by means of short-term, medium-term or long-term measures.

\section{Military Supply Network}

An efficient military supply network is necessary for avoiding the logistics culmination [5]. This occurs when the resources cannot be reconciled with the required demands.

In the context of traditional military supply, the higher level of command delivers supplies to the lower level of command, or they are picked up from there. However, in current and increasingly also in future operations, the involvement of external logistical service providers is essential to ensure sustainability. For example, logistics services can be provided by the host country (Host Nation Support) or by civilian companies (Contractor Support to Operations). The involvement of various partners creates a supply network in military logistics with different actors working in the logistics assurance process. Essentially, it is "a flexible set of supply chains connecting points of production and use, ensuring the most appropriate and efficient use of resources across the Whole Force, maximizing information and technology to assure logistic support to operational commanders [6]."

Infrastructural necessities and physical lines of communication are essential for the execution of logistics implementation tasks. Ports or facilities usable for logistics, as well as roads, sea lines or airways are basic elements of the supply network.

However, non-physical lines of communication are also necessary, as military logistics depends on timely, adequate and secure information. These information flows are essential to coordinate and control the flow of supplies from different demand coverers to the different customers.

Critical to the design of the military logistics network is the definition of clear responsibilities and consideration of appropriate flexibility and simplicity.

\section{Risk management}

The threat of damage from unforeseen events such as accidents, natural disasters or terrorist attacks vividly illustrates the urgency of a comprehensive risk management. The fundamental task is to identify potential risks and provide a corresponding concept of countermeasures. Knowledge of the respective risk situation is the starting point for risk management as a conscious decision to deal with relevant risks. These aspects also apply to the military supply network, which primarily serves to ensure the sustainability of armed forces.

The purpose of risk management is not to avoid risks, but to identify them and provide a basis for decision-making for operational or tactical considerations [7]. To achieve this goal, the individual steps of risk management (risk management planning, risk identification, risk analysis and evaluation, risk treatment, and risk 
monitoring) must be an integral part of the overall Military Decision Making Process (either tactical or operational level), and reflects the culture, processes and operating procedures [8].

\subsection{Risk Management Planning}

The first phase of risk management includes preparatory activities such as the creation of a risk treatment procedure. The risk management plan describes how risks are to be identified, analysed and mitigated in accordance with specific risk classification criteria, explains specific details on how and when each risk management activity is to take place, and distributes the responsibilities among staff members [9]. It also coordinates the communication and consultation during all stages of the risk management process.

\subsection{Risk Identification}

The risk identification phase comprises the systematic, structured discovery and documentation of risks, focusing on the essential aspects.

A risk results in terms of cause from the uncertainty of future events and may lead to a negative achievement of the objectives of a military operation [10]. To identify risks to a military supply network, it is necessary to distinguish risks by their origin between external and internal risks [11]. While external risks arise in the supply network environment and their occurrence can only be partially influenced, internal risks originate within the Armed Forces and provide better opportunities for mitigation (see Table 1).

Table 1 External and internal risks

\begin{tabular}{|c|c|c|}
\hline Risk Type & Risk Name & Risk Characteristics \\
\hline \multirow{3}{*}{ External } & $\begin{array}{l}\text { Demand } \\
\text { risk }\end{array}$ & Unpredictable or misunderstood customer demand \\
\hline & $\begin{array}{l}\text { Environmental } \\
\text { risk }\end{array}$ & $\begin{array}{l}\text { Interruptions related to economic, social, } \\
\text { governmental, or climate factors }\end{array}$ \\
\hline & $\begin{array}{l}\text { Business } \\
\text { risk }\end{array}$ & $\begin{array}{l}\text { Instability of a supplier or the infrastructure within } \\
\text { the supply network }\end{array}$ \\
\hline \multirow{3}{*}{ Internal } & $\begin{array}{l}\text { Planning and control } \\
\text { risk }\end{array}$ & $\begin{array}{l}\text { Unclear or not regulated internal processes (planning, } \\
\text { realization, assessment and controlling) }\end{array}$ \\
\hline & $\begin{array}{l}\text { Business } \\
\text { risk }\end{array}$ & $\begin{array}{l}\text { Changes in key personnel, management, reporting } \\
\text { structures or business processes }\end{array}$ \\
\hline & $\begin{array}{l}\text { Manufacturing } \\
\text { risk }\end{array}$ & Interruption of internal production \\
\hline
\end{tabular}

The clustering of the identified risks, which can occur within the supply network, is a precondition for the following risk analysis and risk evaluation phase [12].

\subsection{Risk Analysis and Evaluation}

The first step, risk analysis, considers the causes and sources of risks, their impact, and the likelihood that those consequences can occur. Factors that affect consequences and likelihood should be identified. The developed scenarios must be sufficiently and clearly described and include causes and effects. This is the only way to make them amenable to risk assessment [13].

The purpose of risk evaluation (second step) is to assist in making decisions, based on the outcomes of risk analysis, about which risks need treatment and the priority for treatment implementation (see Figure 1). 


\begin{tabular}{|c|c|c|c|c|c|c|}
\hline & & & \multicolumn{4}{|c|}{ Impact } \\
\hline & & & Acceptable & Tolerable & Unacceptable & Intolerable \\
\hline & & & Little or no effect & Effect is not critical & $\begin{array}{l}\text { Effect has a serious } \\
\text { impact }\end{array}$ & $\begin{array}{l}\text { Effect could result } \\
\text { in disaster }\end{array}$ \\
\hline \multirow{3}{*}{ 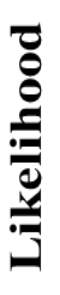 } & Improbable & $\begin{array}{l}\text { Risk unlikely } \\
\text { to occur }\end{array}$ & & & & \\
\hline & Possible & $\begin{array}{l}\text { Risk will } \\
\text { likely occur }\end{array}$ & & & & \\
\hline & Probable & $\begin{array}{l}\text { Risk will } \\
\text { occur }\end{array}$ & & & & \\
\hline
\end{tabular}

Figure 1: Risk matrix - Example

\subsection{Risk Treatment}

Risk treatment involves selecting one or more options for modifying risks, and implementing those options. This includes a description of the various possible alternative actions on how to deal with the risks and the implementation of a risk mitigation plan for selected risks. Knowledge of the relative importance of the individual risks and the overall scope of the threat can be used to derive the need for action for targeted risk management. This can be aimed at avoiding risks, limiting the extent of damage or reducing the probability of occurrence [14].

In principal, there are four main options for the handling of risks (avoid, transfer, reduce or accept):

(1) If a risk is deemed too high, then the activity that creates the risk should be avoided.

(2) In many instances, the risk can be transferred to another provider by outsourcing the process.

(3) Risk reduction is one of the most crucial steps for processes or activities that cannot be avoided, and where risk cannot be transferred to another party.

(4) For some processes and activities, there is no option but to accept the risk. However, these instances should only involve low risk, or repercussions that are easily managed. Some risks might be completely acceptable and require no action at all.

Selecting the most appropriate risk treatment option involves balancing the effort and cost of implementation against the likely benefits, with regard to legal, regulatory, and other requirements. It is important, that the developed treatment plans do not conflict with the other plans.

\subsection{Risk Monitoring}

This phase consists of monitoring the effectiveness of the risk mitigation plans, reassessing the residual risks and identifying any new risks [15].

For successful implementation of the risk management process, it is necessary that all activities of the risk treatment plans are continuously monitored. Only in this way, actual risk occurrences can be identified as early as possible and control measures can be initiated. In this context, it is appropriate to define relevant early warning indicators for potential risks. Furthermore, risk monitoring frequently uncovers risk-critical areas that have not yet been identified. If necessary, more in-depth risk analyses should be carried out in these areas [16].

\section{Conclusions}

Crises, such as the current Corona crisis, relentlessly expose the instability and vulnerability of a supply network through increasingly efficient and interconnected logistics processes. However, this does not only apply to civilian enterprises. The sustainability of armed forces also depends 
on functioning supply chains. In order to be better prepared for the future, it is therefore necessary to strengthen the resilience of the military supply network. To this end, risk management must be implemented at the appropriate military command levels in order to be able to take the right measures.

Starting with the military strategic level and continuing to the operational and tactical level, a consistent, plausible and functioning instrument dealing with risk management planning, risk identification, risk analysis and evaluation, risk treatment, and risk monitoring must be introduced.

For this purpose, it is necessary to create an awareness that a permanent flow of goods, people and information within the supply network is essential for the fulfilment of the stated objectives.

\section{References List}

[1] Huth M., Romeike F. Grundlagen des Risikomanagements in der Logistik. In: Huth M., Romeike F., editors. Risikomanagement in der Logistik. Wiesbaden: Springer Fachmedien; 2016, p. 33.

[2] Schulte-Zurhausen, M. Organisation. München: Verlag Franz Vahlen; 2010, p. 288.

[3] Dillerup R., Stoi R. Unternehmensführung. München: Franz Vahlen; 2016, p. 514.

[4] Pfohl H.C. Logistikmanagement. Heidelberg: Springer Verlag, 2016; p. 332.

[5] Kress M. Operational Logistics. $2^{\text {nd }}$ edition. New York: Springer International Publishing; 2016. p. 74.

[6] Ministry of Defence. Joint Doctrine Publication 4-00, Logistics for Joint Operations. Swindon: MOD; 2015. p. 9.

[7] Meierbeck R. Strategisches Risikomanagement der Beschaffung. Brandsberg: Josef Eul Verlag; 2019. p. 26.

[8] NATO Standardization Office. Allied Joint Doctrine for the Conduct of Operations. AJP-3(C). Brussels: NATO; 2019. p. D-6.

[9] Eschlbeck D., Süß G. Der Projektmanagement-Kompass. Wiesbaden: Friedrich Vieweg \& Sohn; 2002, p. 81.

[10] Meierbeck R. Strategisches Risikomanagement der Beschaffung. Brandsberg: Josef Eul Verlag; 2019, p. 18.

[11] Hoffmann J. Risikomanagement in Logistikunternehmen und Logistiknetzwerken. Norderstedt: Books on Demand; 2014, p. 280.

[12] Brühwiler B. Notwendigkeit und Nutzen von internationalen Standards im LogistikRisikomanagement. In: Huth M., Romeike F., editors. Risikomanagement in der Logistik. Wiesbaden: Springer Fachmedien; 2016, p. 165.

[13] Brühwiler B. Notwendigkeit und Nutzen von internationalen Standards im LogistikRisikomanagement. In: Huth M., Romeike F., editors. Risikomanagement in der Logistik. Wiesbaden: Springer Fachmedien; 2016, p. 166.

[14] Thomas Berger, Werner Gleißner: Risikomanagement - Prozesse und Organisation. Ohne Ort: Bookboon; 2010, p. 47.

[15] Thomas Berger, Werner Gleißner: Risikomanagement - Prozesse und Organisation. Ohne Ort: Bookboon; 2010, p. 58.

[16] Strohmeier G. Ganzheitliches Risikomanagement in Industriebetrieben. Wiesbaden: Deutscher Universitäts-Verlag; 2007. p. 51. 